\title{
Marker-assisted sex differentiation in date palm using simple sequence repeats
}

\author{
Khaled Elmeer • Imene Mattat
}

Received: 5 January 2012/ Accepted: 21 February 2012/Published online: 6 March 2012

(C) The Author(s) 2012. This article is published with open access at Springerlink.com

\begin{abstract}
Microsatellite markers containing simple sequence repeats (SSRs) are a valuable tool for genetic analysis. Our objective was to identify microsatellite markers that could be used to differentiate between male and female date palm (Phoenix dactylifera). The date palm is a dioecious plant whose sex cannot be determined until it reaches a reproductive age between 5 and 10 years. An early selection and/or differentiation of young seedlings into males and females could enhance breeding and assist research programs for genetic improvements of the date palm. Here, we report on the use of microsatellites for determining the sex of immature date palm. Using 14 microsatellite primer pairs with 129 date palm leaves and tissue culture samples from 34 cultivars which represent the major date palm diversity of Qatar, 254 microsatellite loci were detected, of these, 22 microsatellite loci could be used to identify 9 out of 12 male date palm samples (75\%). The data also indicated that the heterozygous allele with the size $160 / 190$ produced by the primer mPdCIR048 reoccurred 4 times exclusively in the 12 individual male samples but not in any of the 117 female date palm samples tested, and hence it is a promising candidate marker to detect male sex in date palm. Principal coordinate analysis (PCoA) of 12 male samples with 7 female Khasab cultivars produced 2 autonomous groups of males and females and similar results were observed with 13 female Shishi cultivars. Our results suggest that the SSR markers described here have potential in sex identification of date palm.
\end{abstract}

K. Elmeer $(\varangle) \cdot$ I. Mattat

Genetic Engineering Department, Biotechnology Centre, Doha, Qatar

e-mail: elmeer@gmail.com
Keywords Phoenix dactylifera - Sex identification . Sex marker $\cdot$ SSR $\cdot$ Microsatellite

\section{Introduction}

Palms (Arecaceae) are a particularly interesting family for the study of dicliny (separate male and female trees), as they display great diversity in their reproductive morphology, with more than $85 \%$ of the palm genera having single sex flowers (Dransfield et al. 2008). Historically, breeding programs to maintain genetic diversity have not been employed because there is no easy and accurate way to distinguish between male and female plants prior to first flowering, which occurs between 5 and 8 years after planting (Aberlenc-Bertossi et al. 2011; Bendiab et al. 1993). Date palm progenies consist of male and female individuals in equal proportions, which has led to the hypothesis that sex is determined genetically (Daher et al. 2010). Based on cytological studies with chromomycin staining, Siljak-Yakovlev et al. (1996) proposed the existence of sex chromosomes in the date palm. However, neither the gene associated with sex determination has been reported to date nor has the process of developmental arrest in sterile sex organs been studied in detail. Siljak-Yakovlev et al. (1996) also illustrate two other important points in understanding sex determination in dioecious species of plants. First, there are often no obvious cytological or genetic differences between male and female plants, and, second, it is often difficult to study the genetic or molecular basis of sex determination in many species of monoecious or dioecious, agronomically important plants simply because of their longevity.

A severe fusarium wilt of date palm, Fusarium oxysporum, recently destroyed date palms throughout Africa. 
The problem was exacerbated by the lack of natural genetic diversity in date palm populations, which may be overcome by introducing genetic variability into populations (especially for traits which confer disease resistance). The ability to type the sex of seedlings would speed this otherwise lengthy process (Juarez and Banks 1998).

In recent years, there have been serious efforts to understand the basis of sex determination in date palm and to develop methods of identifying the gender at an early stage using isozymes (Torres and Tisserat 1980), peroxydases (Majourhat et al. 2002), and molecular marker tools using random amplified polymorphic DNA (RAPD) (Moghaieb et al. 2010).

In this paper, we have attempted to identify sex-specific DNA markers for date palm cultivars using a microsatellite molecular technique. Such a technique would not only facilitate the identification and selection of good male pollinators for use in breeding programs but could also be used to select date palm with characteristics of high fruit yield, and an improved physical and chemical characteristic of the fruits.

\section{Materials and methods}

Plant material

Leaves and tissue culture samples from 117 female and 12 male date palms, comprising 34 cultivars, were collected from different locations in Qatar (Table 1). These cultivars represent the diversity of date palm genotypes in the Qatari date palm plantation. Young leaves from mature trees, randomly sampled, were collected and stored at $-80{ }^{\circ} \mathrm{C}$ until DNA extraction.

\section{DNA extraction}

The frozen young leaf tissues were cleaned carefully with distilled water to remove the waxy layer and then $1 \mathrm{~g}$ of each leaf sample was cut into small pieces and grounded using liquid nitrogen into a fine powder. The DNA was extracted using the DNeasy Plant Maxi kit protocol (QIAGEN), following the manufacturer's instructions outlined in the DNeasy Plant Handbook. The DNA samples obtained were quantified using NanoDrop ${ }^{\circledR}$ ND 1000 Spectrophotometer (Thermo Fisher Scientific) and the quality was determined by electrophoresis of DNA samples $(2 \mu \mathrm{L})$ loaded on $0.85 \%$ agarose gels and separated at $100 \mathrm{~V}$ for $30 \mathrm{~min}$, following which the gel was stained with ethidium bromide and viewed under UV transilluminator.
Table 1 Cultivars and tissue culture samples of date palm (Phoenix dactylifer) from Qatar used in this study

\begin{tabular}{|c|c|c|c|c|c|}
\hline \multirow[t]{2}{*}{ Cultivar } & \multicolumn{4}{|c|}{ Location } & \multirow[t]{2}{*}{ Tissue culture } \\
\hline & North & East & West & South & \\
\hline Khalas & 7 & 5 & 2 & 3 & 1 \\
\hline Shishi & 2 & 5 & 2 & 3 & 1 \\
\hline Barhi & 2 & 3 & 1 & 3 & 1 \\
\hline Khnaizi & 1 & 4 & 2 & 3 & 1 \\
\hline Hillali & 1 & 3 & 2 & 1 & 1 \\
\hline Khasab & 1 & 3 & 1 & 2 & 0 \\
\hline Gar & 2 & 2 & 0 & 0 & 1 \\
\hline Jabri & 1 & 1 & 1 & 0 & 1 \\
\hline Lulu & 0 & 2 & 2 & 0 & 0 \\
\hline Rzaiz & 0 & 0 & 0 & 3 & 1 \\
\hline Nabetseaf & 1 & 1 & 1 & 0 & 0 \\
\hline Shahil & 1 & 0 & 1 & 1 & 0 \\
\hline Shabishi & 0 & 1 & 2 & 0 & 0 \\
\hline Sukari & 0 & 1 & 1 & 1 & 0 \\
\hline Iraqi & 0 & 0 & 1 & 1 & 0 \\
\hline Deqlah & 0 & 0 & 0 & 1 & 0 \\
\hline Gher & 0 & 1 & 0 & 0 & 0 \\
\hline Marzban & 1 & 0 & 0 & 0 & 0 \\
\hline Tanazel & 0 & 0 & 1 & 0 & 0 \\
\hline Abumaan & 0 & 0 & 0 & 0 & 1 \\
\hline Farthabaid & 0 & 0 & 0 & 0 & 1 \\
\hline Zamli & 0 & 0 & 0 & 0 & 1 \\
\hline Kathrawi & 0 & 0 & 0 & 0 & 1 \\
\hline JeshRamli & 0 & 0 & 0 & 0 & 1 \\
\hline Nawader & 0 & 0 & 0 & 0 & 1 \\
\hline Hiri & 0 & 0 & 0 & 0 & 1 \\
\hline Madayen & 0 & 0 & 0 & 0 & 1 \\
\hline Namshi & 0 & 0 & 0 & 0 & 1 \\
\hline Ghanami & 0 & 0 & 0 & 0 & 1 \\
\hline UmDehan & 0 & 0 & 0 & 0 & 1 \\
\hline Madjoul & 0 & 0 & 0 & 0 & 1 \\
\hline Saaqi & 0 & 0 & 0 & 0 & 1 \\
\hline FemaleR & 0 & 0 & 1 & 0 & 0 \\
\hline FemaleY & 0 & 0 & 1 & 0 & 0 \\
\hline Male & 0 & 4 & 5 & 3 & 0 \\
\hline
\end{tabular}

A total of 129 date palm samples representing 34 cultivars were collected

Microsatellite amplification

Fourteen labeled primer pairs as described by Billotte et al. (2004) were synthesized by Applied Biosystems (Belgium, Life Technologies Europe BV) and are presented in Table 2. A polymerase chain reaction (PCR) was performed using $25 \mu \mathrm{L}$ of a reaction mixture containing $2 \mu \mathrm{L}$ (5 ng) of total genomic DNA, $12.5 \mu \mathrm{L}$ of AmpliTaq Gold ${ }^{\circledR}$ 
Table 2 Forward and reverse microsatellite primers and their $T_{\mathrm{m}}$ used in this study (Billotte et al. 2004)

\begin{tabular}{|c|c|c|c|c|}
\hline No. & Primer code & Repeat motif & Primer sequences $\left(5^{\prime}-3^{\prime}\right)$ & Optimal $T_{\mathrm{m}}\left({ }^{\circ} \mathrm{C}\right)$ \\
\hline 1 & mPdCIR010 & $(\mathrm{GA})_{22}$ & $\begin{array}{l}\text { F: ACCCCGGACGTGAGGTG } \\
\text { R: CGTCGATCTCCTCCTTTGTCTC }\end{array}$ & 55.9 \\
\hline 2 & mPdCIR015 & $(\mathrm{GA})_{15}$ & $\begin{array}{l}\text { F: AGCTGGCTCCTCCCTTCTTA } \\
\text { R: GCTCGGTTGGACTTGTTCT }\end{array}$ & 51.6 \\
\hline 3 & mPdCIR016 & $(\mathrm{GA})_{14}$ & $\begin{array}{l}\text { F: AGCGGGAAATGAAAAGGTAT } \\
\text { R: ATGAAAACGTGCCAAATGTC }\end{array}$ & 51.7 \\
\hline 4 & mPdCIR025 & $(\mathrm{GA})_{22}$ & $\begin{array}{l}\text { F: GCACGAGAAGGCTTATAGT } \\
\text { R: CCCCTCATTAGGATTCTAC }\end{array}$ & 49.3 \\
\hline 5 & mPdCIR032 & $(\mathrm{GA})_{19}$ & $\begin{array}{l}\text { F: CAAATCTTTGCCGTGAG } \\
\text { R: GGTGTGGAGTAATCATGTAGTAG }\end{array}$ & 51.5 \\
\hline 6 & mPdCIR035 & $(\mathrm{GA})_{15}$ & $\begin{array}{l}\text { F: ACAAACGGCGATGGGATTAC } \\
\text { R: CCGCAGCTCACCTCTTCTAT }\end{array}$ & 53.9 \\
\hline 7 & mPdCIR044 & $(\mathrm{GA})_{19}$ & $\begin{array}{l}\text { F: ATGCGGACTACACTATTCTAC } \\
\text { R: GGTGATTGACTTTCTTTGAG }\end{array}$ & 51.7 \\
\hline 8 & mPdCIR048 & $(\mathrm{GA})_{32}$ & $\begin{array}{l}\text { F: CGAGACCTACCTTCAACAAA } \\
\text { R: CCACCAACCAAATCAAACAC }\end{array}$ & 51.4 \\
\hline 9 & mPdCIR057 & $(\mathrm{GA})_{20}$ & $\begin{array}{l}\text { F: AAGCAGCAGCCCTTCCGTAG } \\
\text { R: GTTCTCACTCGCCCAAAAATAC }\end{array}$ & 55.4 \\
\hline 10 & mPdCIR070 & $(\mathrm{GA})_{17}$ & $\begin{array}{l}\text { F: CAAGACCCAAGGCTAAC } \\
\text { R: GGAGGTGGCTTTGTAGTAT }\end{array}$ & 48.7 \\
\hline 11 & mPdCIR078 & $(\mathrm{GA})_{13}$ & $\begin{array}{l}\text { F: TGGATTTCCATTGTGAG } \\
\text { R: CCCGAAGAGACGCTATT }\end{array}$ & 49.6 \\
\hline 12 & mPdCIR085 & $(\mathrm{GA})_{29}$ & $\begin{array}{l}\text { F: GAGAGAGGGTGGTGTTATT } \\
\text { R: TTCATCCAGAACCACAGTA }\end{array}$ & 50.4 \\
\hline 13 & mPdCIR090 & $(\mathrm{GA})_{26}$ & $\begin{array}{l}\text { F: GCAGTCAGTCCCTCATA } \\
\text { F: GCAGTCAGTCCCTCATA }\end{array}$ & 48.6 \\
\hline 14 & mPdCIR093 & $(\mathrm{GA})_{16}$ & $\begin{array}{l}\text { F: CCATTTATCATTCCCTCTCTTG } \\
\text { R: CTTGGTAGCTGCGTTTCTTG }\end{array}$ & 51.8 \\
\hline
\end{tabular}

360 Mastermix (Applied Biosystems), $1 \mu \mathrm{L}(5 \mathrm{pmol} / \mu \mathrm{L})$ of forward primer (labeled), and $1 \mu \mathrm{L}$ of reverse primer in addition to $8.5 \mu \mathrm{L}$ of nuclease free water. Amplification was carried out in a Veriti 96 Well Fast Thermal cycler (Applied Biosystems) under the following conditions: initial denaturation at $95{ }^{\circ} \mathrm{C}$ for $10 \mathrm{~min}, 35$ cycles (denaturation at $95{ }^{\circ} \mathrm{C}$ for $30 \mathrm{~s}$, annealing temperature depending on primer for $30 \mathrm{~s}$, and extension at $72{ }^{\circ} \mathrm{C}$ for $1 \mathrm{~min}$ ), and final extension at $72{ }^{\circ} \mathrm{C}$ for $7 \mathrm{~min}$.

\section{SSR fragment analysis}

Simple sequence repeats (SSRs) were screened on a 3130 Genetic Analyzer (Applied Biosystems) by running $1 \mu \mathrm{L}$ of PCR product mixed with $10 \mu \mathrm{L}$ Hi-Di formamide and $0.3 \mu \mathrm{L}$ GS500LIZ followed by denaturation at $95{ }^{\circ} \mathrm{C}$ for $3 \mathrm{~min}$. The sample was then kept on ice for genotyping in a 3130 Genetic Analyzer. Automatic genotyping and allele scoring were performed by the GeneMapper ${ }^{\circledR}$ software v4.0 (Applied Biosystems).
Data analysis

The data were analyzed with PowerMarker software v3.0 (Liu and Muse 2005) to determine the percentage of heterozygosity, major allele frequency, number of alleles, gene diversity, and polymorphic information content (PIC).

The principal coordinate analysis (PCoA) of the male date palm with Shishi and Khasab cultivars was analyzed and drawn using PAST software v1.91 (Hammer et al. 2001) based on the Hamming distance measures by convex hulls.

\section{Results and discussion}

The microsatellites examined were highly polymorphic, possessing a great number of alleles. A total of 124 alleles with a mean of 8.86 alleles per locus were scored, however, the number of alleles varied from 3 using primer $\mathrm{mPd}$ CIR090 to 13 using primers mPdCIR010 and mPdCIR078 
Table 3 Genetic diversity information by locus

\begin{tabular}{|c|c|c|c|c|c|c|c|}
\hline Primer code & Allelic range & $\begin{array}{l}\text { Major allele } \\
\text { frequency }\end{array}$ & Genotype no. & Allele no. & $\begin{array}{l}\text { Gene } \\
\text { diversity }\end{array}$ & Heterozygosity & PIC \\
\hline mPdCIR010 & $120-162$ & 0.29 & 31.00 & 13.00 & 0.83 & 0.95 & 0.81 \\
\hline mPdCIR015 & $120-140$ & 0.17 & 36.00 & 11.00 & 0.88 & 0.89 & 0.87 \\
\hline mPdCIR016 & $130-138$ & 0.47 & 12.00 & 5.00 & 0.68 & 0.55 & 0.64 \\
\hline mPdCIR025 & 199-231 & 0.65 & 12.00 & 8.00 & 0.52 & 0.45 & 0.47 \\
\hline mPdCIR032 & $288-302$ & 0.47 & 17.00 & 8.00 & 0.71 & 0.78 & 0.67 \\
\hline mPdCIR035 & 181-199 & 0.41 & 15.00 & 8.00 & 0.70 & 0.74 & 0.64 \\
\hline mPdCIR044 & $288-302$ & 0.39 & 13.00 & 7.00 & 0.71 & 0.10 & 0.67 \\
\hline mPdCIR048 & $160-192$ & 0.42 & 16.00 & 10.00 & 0.70 & 0.39 & 0.65 \\
\hline mPdCIR057 & $256-270$ & 0.66 & 9.00 & 6.00 & 0.51 & 0.48 & 0.46 \\
\hline mPdCIR070 & $182-206$ & 0.38 & 16.00 & 11.00 & 0.73 & 0.58 & 0.69 \\
\hline mPdCIR078 & $118-152$ & 0.21 & 31.00 & 13.00 & 0.86 & 0.60 & 0.85 \\
\hline mPdCIR085 & $160-182$ & 0.25 & 26.00 & 9.00 & 0.83 & 0.90 & 0.81 \\
\hline mPdCIR090 & $144-158$ & 0.52 & 3.00 & 3.00 & 0.62 & 0.00 & 0.55 \\
\hline mPdCIR093 & $153-183$ & 0.42 & 17.00 & 12.00 & 0.51 & 0.44 & 0.47 \\
\hline Mean & & 0.47 & 18.14 & 8.86 & 0.70 & 0.56 & 0.66 \\
\hline
\end{tabular}

PIC polymorphic information content

(Table 3). The number of alleles per locus detected in this study was higher than those scored by Zehdi et al. (2004) who recognized 7.14 alleles per locus when examining 46 Tunisian date palm accessions using 14 microsatellite loci. On the other hand, Elshibli and Korpelainen (2007) identified 21.4 alleles per locus, which is more than the number of alleles per locus detected in this study. This may be a result of using a greater number of microsatellite loci (16) in addition to using different genotypes-68 Sudan and Morocco date palm accessions.

The 14 primers used in this study successfully produced clear amplified SSR bands with sizes ranging from $118 \mathrm{bp}$ with primer mPdCIR078 to $302 \mathrm{bp}$ with primers $\mathrm{mPd}$ CIR044 and mPdCIR032 (Table 3), similar to the results of Ahmed and Al-Qaradawi (2009) where the band sizes ranged from 100 to $300 \mathrm{bp}$.

Interestingly, the 14 microsatellite primers used with the 117 female and 12 male date palm samples used in this study formed 254 microsatellite loci with a mean of 10.4 per primer (Table 3 ). The highest was 36 different microsatellite loci scored with primer mPdCIR015, but only 3 different microsatellite loci were scored with primer mPdCIR090.

In a number of agriculturally important plants, such as kiwi fruit, date palm, hops, papaya, and pistachio, the females produce the commercial harvest, while in some others, such as asparagus, males provide the better quality produce. Identification of the sex of such plants at their early stage of growth can be of great economic potential. Moreover, studies on marker technology regarding dioecy in general would provide a better understanding of the developmental (Ainsworth et al. 1998) as well as evolution pathways of dimorphism (Charlesworth and Charlesworth 1978; Charlesworth 1996).

Three primers (mPdCIR035, mPdCIR044, and mPdCIR090) could not distinguish between male and female samples (Table 4) whereas the remaining 11 microsatellite primers identified 22 loci, in only the male date palm samples. Using these loci, 9 of $12(75 \%)$ male plants tested were recognized. Moreover, $82 \%$ of those loci were heterozygous alleles (Table 4), which is in agreement with the finding of Al-Dous et al. (2011) who scanned 3.5 million SNP genotypes in the male and female genomes of date palm to identify polymorphisms that segregate with gender. They observed that all male genomes shared mainly the same heterozygous genotypes, whereas female genomes shared mainly the same homozygous genotypes, while primer mPdCIR010 detected only one heterozygous allele even as the remaining three alleles were homozygous (Table 4). Sexually antagonistic polymorphisms are polymorphisms in which the allele is advantageous to one sex but is deleterious to the other sex. In an influential paper, Rice (1984) hypothesized that such polymorphisms should be relatively common on the $\mathrm{X}$ chromosome (or on the $\mathrm{W}$ in female-heterogametic species) but relatively rare on the autosomes. Yet, Fry (2010) showed that there are plausible assumptions under which the reverse is expected to be true, and pointed out studies that gave evidence for sexually antagonistic variation on the autosomes. Although more work is needed to resolve the issue, it is premature to conclude that the X chromosome is a "hot spot" for the accumulation of sexually antagonistic variation. 
Table 4 Twenty two loci hetero and homozygous allele (base pairs) markers that identify male date palm trees

\begin{tabular}{|c|c|c|c|c|c|c|c|c|c|}
\hline Locus code & Male 1 & Male 2 & Male 4 & Male 5 & Male 6 & Male 8 & Male 10 & Male 11 & Male 12 \\
\hline mPdCIR010 & $126 / 128$ & - & - & - & $144 / 144$ & - & - & $122 / 122$ & $134 / 134$ \\
\hline mPdCIR015 & - & - & $124 / 126$ & - & $130 / 134$ & - & - & - & $128 / 134$ \\
\hline mPdCIR016 & - & - & - & - & - & - & - & - & $130 / 134$ \\
\hline mPdCIR025 & - & - & - & $213 / 229$ & - & - & - & - & - \\
\hline mPdCIR032 & - & - & $290 / 294$ & - & $294 / 298$ & $300 / 300$ & - & - & - \\
\hline mPdCIR048 & - & $160 / 190$ & $160 / 190$ & - & - & $160 / 184$ & $160 / 192$ & $160 / 190$ & $160 / 190$ \\
\hline mPdCIR057 & - & - & - & - & - & - & - & - & $260 / 266$ \\
\hline mPdCIR070 & - & - & - & - & - & - & - & $198 / 204$ & - \\
\hline mPdCIR078 & - & $122 / 140$ & - & - & - & - & $122 / 140$ & - & $134 / 142$ \\
\hline mPdCIR085 & - & - & - & - & $160 / 162$ & - & - & - & - \\
\hline mPdCIR093 & - & $163 / 175$ & - & - & $169 / 175$ & $163 / 175$ & - & - & - \\
\hline
\end{tabular}

Primers with code mPdCIR035, mPdCIR044, and mPdCIR090 could not differentiate male and female date palm samples due to no amplification of distinguished markers in male plants therefore have been excluded from the table. For males 3, 7, and 9, no distinguished loci were detected and hence these samples have been excluded from the table

For male 12, 6 markers were detected while just one specific marker was detected for male 1 . However, for males 3, 7, and 9, no markers were detected (Table 4).

Male associated DNA fragments have previously been identified by random amplification of polymorphic DNA (RAPD) in many dioecious plants. Sakamoto et al. (1995) cloned a 730 bp long DNA fragment named MADCl (male associated DNA sequence) in Cannabis sativa. However, MADC1 does not include a long ORF and is not likely to correspond to a transcribed gene (Sakamoto et al. 1995). Using representational difference analysis, several male sex-specific restriction fragments in Silene latifolia have been isolated and cloned. These male-specific restriction fragments were found to be homologous to other sequences shared between male and female plants (Domison et al. 1996).

The mean of the gene diversity was 0.70 (Table 3), ranging from 0.51 for loci mPdCIR057 and mPdCIR093 to high diversity 0.88 for locus $\mathrm{mPdCIR} 015$, indicating that the Qatari date palm collection is characterized by a high degree of genetic diversity. This level of gene diversity is similar to 0.70 reported for the Tunisian date palm germplasm (Zehdi et al. 2004) and less than 0.853 reported for the Sudanese date palm (Elshibli and Korpelainen 2007). This high level of diversity is expected because of the unique mechanism responsible for generating SSR allelic diversity by replication slippage. Replication slippage is thought to occur more frequently than single nucleotide mutations and insertion/deletion events, which generate the polymorphisms detected by RAPD analysis (Powell et al. 1996).

The heterozygous allele sized 160/190 exhibited by primer mPdCIR048 (Table 4) seems to be a distinguishing marker for sex in date palm because it appeared 4 times in the 12 individual male date palm trees tested. At the same time, no sign of this marker was detected in 117 individual female date palm trees. The two following alleles sized $122 / 140$ (exhibited by the primer mPdCIR078) and 163/175 (exhibited by the primer mPdCIR093), respectively, were repeated twice in the 12 individual male date palm tree tested. Again, there was no sign of these alleles in the 117 individual female date palm trees.

The data obtained from the 14 primers combinations enabled the samples of the two date palm cultivars Shishi and Khasab to be classified into the two groups according to their sex expression compared with male trees using principal coordinate analysis (PCoA) (Gower 1966) using the PAST software v1.91 (Hammer et al. 2001). The Hamming distance was chosen in preference to other distance measures, as it does not class a common absence of an allele as a shared characteristic. It was, therefore, judged to be most appropriate for the present study, which included highly polymorphic microsatellite data spanning two ploidy levels.

PCoA suggests two broad groups-one includes 7 female Khasab trees (Fig. 1) while the other is made up of 12 male date palm trees which are autonomous with $21 \%$ of the variation explained by the first axis and $17 \%$ by the second axis. The same two groups separate 13 female Shishi trees from the 12 male date palm trees (Fig. 2). There is a limited overlap between the two groups. Twenty percent of the variation is explained by the first axis while $13 \%$ of the variation is explained by the second axis.

Farmers are currently faced with distinguishing between cultivars propagated by seeds. The use of vegetative and flowering characteristics (Rhouma 1994) or the isozyme markers (Mohamed Ould et al. 2001) are less rewarding, since these traits take a long time-between 5 and 7 years-to become visible. Fortunately, the SSR alleles 


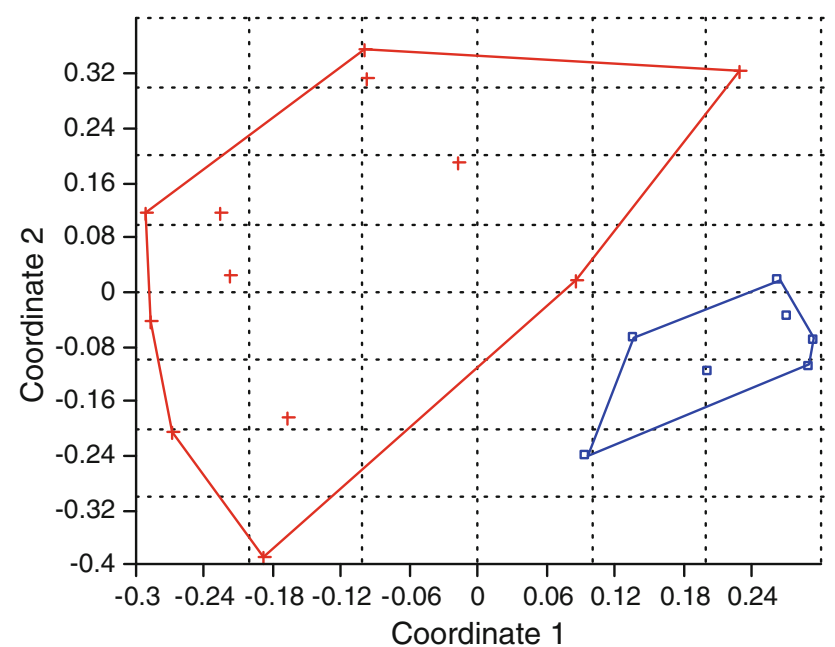

Fig. 1 Scatter plot of the first and second principal coordinate analysis (PCoA) of 7 female Khasab cultivars (blue) and 12 male date palms (red) using Hamming distance measures on convex hulls based on the SSR obtained for the 14 primer combinations

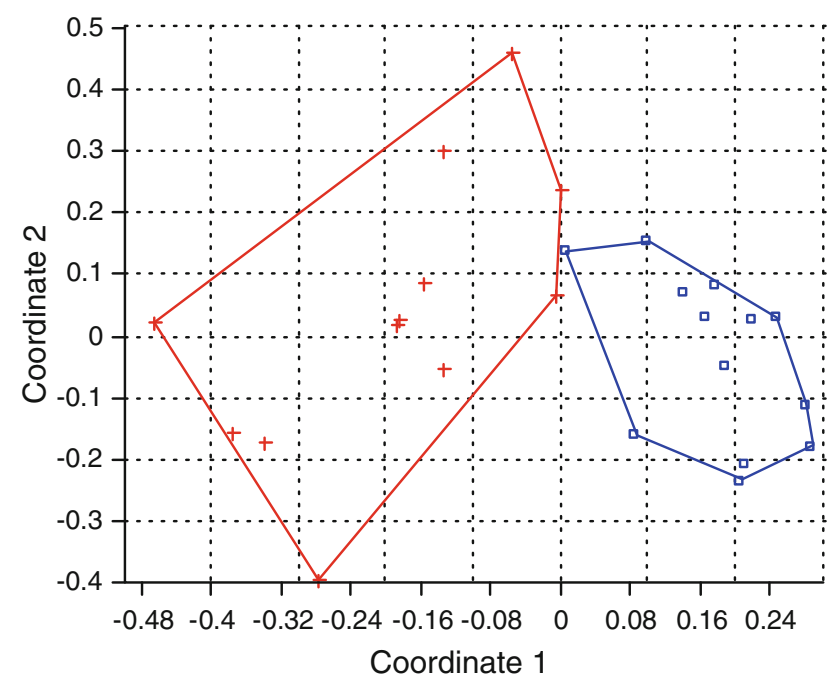

Fig. 2 Scatter plot of the first and second principal coordinate analysis (PCoA) of 13 female Shishi cultivars (blue) and 12 male date palms (red) using Hamming distance measures on convex hulls based on the SSR obtained for 14 primer combinations

revealed were successfully used to molecularly discriminate between a nearly unlimited number of date palm cultivars. Compared to other reported date palm studies, the outcome in this study is more accurate than that observed using isoenzymes (Booij et al. 1995; Mohamed Ould et al. 2001) and plastid DNA haplotypes (Sakka 2003). Our data provide evidence that these powerful markers can be used as key identifiers of the sex in date palm materials.

Acknowledgments This work was supported by the grant from The International Center for Agricultural Research in the Dry Areas
(ICARDA), under the scheme of Development of Sustainable Date Palm Production Systems in the GCC Countries of the Arabian Peninsula.

Open Access This article is distributed under the terms of the Creative Commons Attribution License which permits any use, distribution, and reproduction in any medium, provided the original author(s) and the source are credited.

\section{References}

Aberlenc-Bertossi F, Daher A, Chabrillange N, Tregear JW, Mohamed N (2011) Sex determination in date palm: new perspectives on an old theme. Plant and animal genomes XIX conference, W519: sex chromosomes and sex determination, January 15-19, 2011. Town and Country Convention Center, San Diego, CA

Ahmed TA, Al-Qaradawi A (2009) Molecular phylogeny of Qatari date palm genotypes using simple sequence repeats markers. Biotechnology 8:126-131

Ainsworth C, Parker J, Buchanan-Wollaston V (1998) Sex determination of plants. Curr Top Dev Biol 38:167-223

Al-Dous EK, George B, Al-Mahmoud ME, Al-Jaber MY, Wang H, Salameh YM, Al-Azwani EK, Chaluvadi S, Pontaroli AC, DeBarry J, Arondel V, Ohlrogge J, Saie IJ, Suliman-Elmeer KM, Bennetzen JL, Kruegger RR, Malek JA (2011) De novo genome sequencing and comparative genomics of date palm (Phoenix dactylifera). Nat biotechnol 29:521-528

Bendiab K, Baaziz M, Brakez Z, My Sedra H (1993) Correlation of isoenzyme polymorphism and Bayoud-disease resistance in date palm cultivars and progeny. Euphytica 65:23-32

Billotte N, Marseillac N, Brottier P, Noyer JL, Jacquemoud-Collet JP et al (2004) Nuclear microsatellite marker for date palm (Phoenix dactylifera): characterization and utility across the genus Phoenix and in other palm genera. Mol Ecol Notes $4: 256-258$

Booij L, Montfort S, Ferry M (1995) Characterization of thirteen date palm (Phoenix dactylifera L.) cultivars by enzyme electrophoresis using the PhastSystem. J Plant Physiol 145:62-66

Charlesworth B (1996) The evolution of chromosomal sex determination and dosage compensation. Curr Biol 6:149-162

Charlesworth B, Charlesworth D (1978) A model for the evolution of dioecy and gynodioecy. Am. Nature 112:975-997

Daher A, Adam H, Chabrillange N, Collin M, Mohamed N, Tregear JW, Aberlenc-Bertossi F (2010) Cell cycle arrest characterizes the transition from a bisexual floral bud to a unisexual flower in Phoenix dactylifera. Ann Bot 106:255-266

Domison IS, Siroky J, Vyskot B, Saedler H, Grant S (1996) Isolation of Y chromosome-specific sequences from Silene latifolia and mapping of the male sex determining genes using representational difference analysis. Genetics 144:1893-1901

Dransfield J, Uhl MW, Amussen CB, Baker WJ, Harley M, Lewis CL (2008) Genera Palmarum: the evolution and classification of palms. Kew Publishing, London

Elshibli S, Korpelainen H (2007) Microsatellite markers reveal high genetic diversity in date palm (Phoenix dactylifera L.) germplasm from Sudan. Genetica 134:251-260

Fry JD (2010) The genomic location of sexually antagonistic variation: some cautionary comments. Evolution 64:1510-1516

Gower JC (1966) Some distance properties of latent root and vector methods used in multivariate analysis. Biometrika 53:325-338

Hammer Z, Harper DAT, Ryan PD (2001) PAST: Paleontological statistics software package for education and data analysis. Palaeontologia Electronica 4(1):9 
Juarez C, Banks J-A (1998) Sex determination in plants. Curr Opin Plant Biol 1:68-72

Liu K, Muse SV (2005) PowerMarker: an integrated analysis environment for genetic marker analysis. Bioinformatics 21(9):2128-2129

Majourhat K, Bendiab K, Medraoui L, Baaziz M (2002) Diversity of leaf peroxidases in date palm (Phoenix dactylifera L.) as revealed in an example of marginal (seedling derived) palm groves. Sci Hortic 95:31-38

Moghaieb REA, Abdel-Hadi AA, Ahmed MRA, Hassan AGM (2010) Genetic diversity and sex determination in date palms (Phoenix dactylifera L.) based on DNA markers. Arab J Biotech 13:143-156

Mohamed Ould, Salem A, Trifi M, Sakka H, Rhouma A, Marrakchi M (2001) Genetic inheritance analysis of four enzymes in date palm (Phoenix dactylifera L.). Genet Resour Crop Evol 48:361-368

Powell W, Morgante MAC, Hanafey M, Vogel J, Tingey S, Rafalski A (1996) The comparison of RFLP, RAPD, AFLP, and SSR (microsatellite) markers for germplasm analysis. Mol Breeding 2:225-238
Rhouma A (1994) Le palmier dattier en Tunisie. I: le patrimoine génétique. Arabesque, Tunis, Tunisie

Rice WR (1984) Sex-chromosomes and the evolution of sexual dimorphism. Evolution 38:735-742

Sakamoto K, Shmomura K, Komeda Y, Kamada H, Satoh S (1995) A male associated DNA sequence in a dioecious plant, Cannabis sativa L. Plant Cell Physiol. 36(1549):1554

Sakka H (2003) Analyse de la diversité génétique chez le palmier dattier (Phoenix dactylifera L.): polymorphisme de l'ADN chloroplastique. $\mathrm{PhD}$ thesis, Université de Tunis El Manar, Faculté de Science, Tunis, Tunisie

Siljak-Yakovlev S, Benmalek S, Cerbah M, Coba de la Peña T, Bounaga N, Brown S, Sarr A (1996) Chromosomal sex determination and heterochromatin structure in date palm. Sex Plant Reprod 9:127-132

Torres AM, Tisserat B (1980) Leaf isozymes as genetic marker in date palm. Amer J Bot 67:162-167

Zehdi S, Trifi M, Billotte N, Marrakchi M, Pintaud JC (2004) Genetic diversity of Tunisian date palms (Phoenix dactylifera L.) revealed by nuclear microsatellite polymorphism. Hereditas $141: 278-287$ 